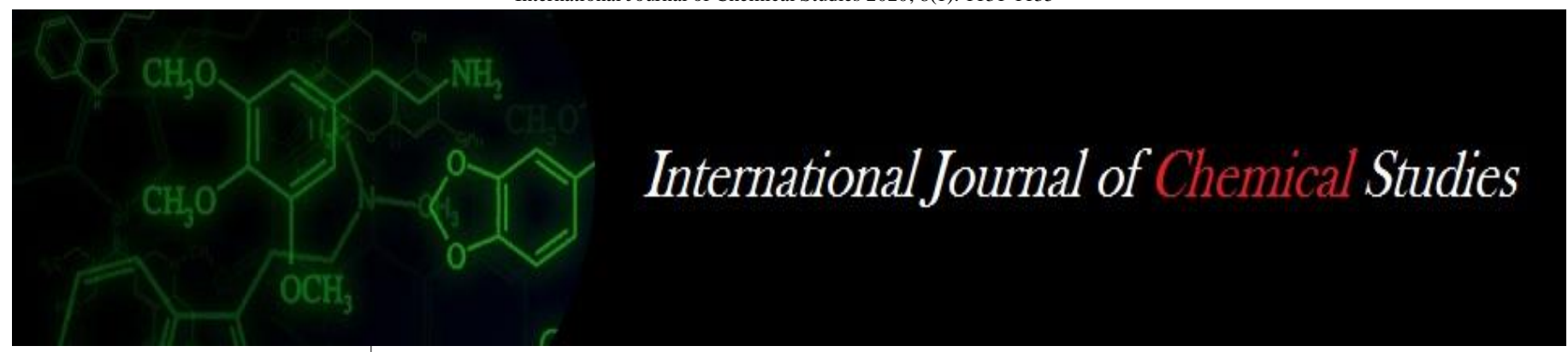

P-ISSN: 2349-8528

E-ISSN: 2321-4902

IJCS 2020; 8(1): 1131-1135

(C) 2020 IJCS

Received: 16-11-2019

Accepted: 18-12-2019

\section{Ulfat Nazir}

Division of Basic Sciences and

Humanities, Faculty of

Agricultural, Sheri Kashmir

University of Agricultural Sciences

and Technology, Kashmir, Jammu

and Kashmir, India

\section{MY Zargar}

Ex Director Research,

Sheri Kashmir University of

Agricultural Sciences and

Technology, Kashmir,

Jammu and Kashmir, India

\section{ZA Baba}

Associate Professor,

Division of Basic Sciences and

Humanities, Faculty of

Agricultural, Sheri Kashmir

University of Agricultural Sciences and Technology, Kashmir, Jammu and Kashmir, India

SA Mir

Professor and Head,

Division of Agri. Statistics, Sheri

Kashmir University of Agricultural

Sciences and Technology, Kashmir,

Jammu and Kashmir, India

\section{FA Mohiddin}

Associate Professor,

MRCFC khudwani, Sheri Kashmir University of Agricultural Sciences and Technology, Kashmir,

Jammu and Kashmir, India

\section{NA Bhat}

Associate Director Research, MRCFC Khudwani, Sheri Kashmir University of Agricultural Sciences and Technology, Kashmir,

Jammu and Kashmir, India
Corresponding Author: Ulfat Nazir

Division of Basic Sciences and

Humanities, Faculty of

Agricultural, Sheri Kashmir

University of Agricultural Sciences and Technology, Kashmir, Jammu and Kashmir, India

\section{Isolation and characterization of plant growth promoting rhizobacteria associated with pea rhizosphere in North Himalayan region}

\author{
Ulfat Nazir, MY Zargar, ZA Baba, SA Mir, FA Mohiddin and NA Bhat
}

DOI: $\underline{\text { https://doi.org/10.22271/chemi.2020.v8.i1o.8401 }}$

\begin{abstract}
PGPR are naturally occurring soil bacteria which actively colonize plant root and benefit plants by promoting growth. They help in providing atmospheric nitrogen, increase supply of other nutrients, produce plant hormones, enhance other beneficial bacteria or fungi, control bacterial and fungal diseases and help in controlling insect pests. The purpose of this study was to investigate the diversity of bacteria associated with the roots of pea and to screen them for selection of most potential PGPR for application in pea crop. The study reveals the diversity of bacterial isolates from soils under pea cultivation in district Srinagar and Baramulla of $\mathrm{J} \& \mathrm{~K}$. The isolates were characterized morphological and physiologically to categorize and identify them. In all 80 different bacterial isolates were recovered from 16 fields of two districts of $\mathrm{J} \& \mathrm{~K}$. The characteristics of the bacterial isolates were determined using the colony morphology, gram staining, biochemical properties and plant growth promoting activities. On the basis of biochemical characterization, 55 isolates belonged to genus Bacillus, 12 to Pseudomonas, 4 to Micrococcus and 9 to Azotobacter. After screening the best nine isolates PGP1, PGP10, PGP28, PGP40, PGP49, PGP52, PGP62, PGP68 and PGP72 were selected for their effect on growth and yield in field conditions using pea as test crop.
\end{abstract}

Keywords: Rhizobacteria, pea, Himalaya, diversity, rhizosphere

\section{Introduction}

Pea (Pisum sativum) is an important vegetable and pulse crop of India. It is relished both as fresh vegetable as well as pulse. Being a legume, it plays an important role in the eco-build up of agriculture, as it enriches the soil by fixing the atmospheric nitrogen. Pea is an important cool season grain legume, which is grown worldwide on over 6 million hectares. Important production areas of the world include France, Russia, Ukraine, Denmark and United Kingdom in Europe; China and India in Asia; Canada and USA in North America; Chile in South America; Ethiopia in Africa, and Australia (FAO, 1994) ${ }^{[9]}$. Peas require a cool, relatively humid climate and are grown at higher altitudes in tropics with temperatures ranging between 7 and $30^{\circ} \mathrm{C}$ (Davies et al., 1985) ${ }^{[6]}$. Peas can be grown successfully during mid-summer and early fall in those areas having relatively low temperatures and a good rainfall, or where irrigation is practiced. The rhizosphere is the thin layer of soil adjacent to plant roots that is influenced by root activities (Hiltner, 1904) ${ }^{[11]}$. There are three separate, but interacting, components recognized in the rhizosphere viz soil, the rhizoplane and root itself. The rhizosphere is the zone of soil influenced by roots through the release of substrates that affect microbial activity. The rhizoplane is the root surface, including the strongly adhering soil particles.

Several microorganisms are able to promote plant growth either directly or indirectly through protection from diseases (Lugtenberg et al., 2004) ${ }^{[17]}$. Besides root colonizing bacteria (rhizobacteria) exert beneficial effect on plant development via direct or indirect mechanisms (Nelson, 2004) [21]. The concept of plant growth promoting rhizobacteria is now well established; both for growth promotion and biocontrol. Plant growth- promoting rhizobacteria (PGPR) were first defined by Kloepper and Schroth (1978) ${ }^{[14]}$ to describe soil bacteria that colonize the roots of plants following inoculation onto seed and they enhance plant growth. However, their ineffectiveness in the field has often been attributed to their inability to colonize plant roots (Benizri et al., 2001; Lugtenberg et al., 2001) ${ }^{[2,18]}$. 
Materials and Methods

Isolation and enumeration of rhizobacteria from pea rhizosphere

Rhizobacteria were isolated from the rhizosphere soil of pea plants during the full bloom stage. To estimate the number of soil microflora, serial dilution technique using the pour plate method was used (Johnson and Curl, 1972) ${ }^{[13]}$. Each value presented in this study is an average of three individual counts. Colony forming units (CFU) were recorded after 48 hours of incubation as per below given formula

$\mathrm{CFU} / \mathrm{gm}=\frac{\text { Bacterial plate count } \times \text { Dilution factor }}{\text { Dry weight of soil }(\mathrm{gm})}$

\section{Estimation of Growth Promoting activities}

\section{Siderophore production}

Siderophore was detected by the formation of orange halos surrounding bacterial colonies on CAS agar plates after incubation for 48 hours at $28^{\circ} \mathrm{C}$ (Schwyan \& Neilands, 1987) [25].

\section{Phosphorous Solubilization}

Phosphate Solubilization was detected by formation of transparent halos surroundings bacterial colonies on the Pikovskaya agar after 72 hour incubation at $28{ }^{\circ} \mathrm{C}$ (Pikovskaya, 1948) ${ }^{[22]}$.

\section{Indole acetic acid production}

Bacterial cultures were incubated in Luria Bertani Broth at 28 ${ }^{\circ} \mathrm{C}$. The bacterial cells were removed from the culture by centrifugation at $8000 \mathrm{~g}$ for $10 \mathrm{~min}$. A $3 \mathrm{ml}$ of supernatant was mixed vigorously with $2 \mathrm{ml}$ of Salkowaski's reagent $\left(2 \mathrm{ml} 0.5 \mathrm{MFeCl}_{3}+98 \mathrm{ml}_{35} \% \mathrm{HCLO}_{4}\right)$ and incubated at room temperature in dark for 30 minutes and observed for pink color formation. (Brick et al., 1991) ${ }^{[4]}$.

\section{Soil Analysis}

The experimental soil was analyzed for various parameters in the beginning and at the end of the investigation. $\mathrm{pH}$ of the soil was determined in 1:2:5 soil solutions using a digital $\mathrm{pH}$ meter. The soil was analyzed for its available nitrogen content by Kjeldhal method (Subbaiah and Asija, 1956) ${ }^{[28]}$ and organic carbon content by wet oxidation method (Jackson, 1967) ${ }^{[12]}$. The available phosphorus content was determined by Olsen's method (Muhur et al., 1965) ${ }^{[19]}$ and the available potassium by flame photometer method (Stanford and English, 1949) ${ }^{[27]}$.

Effect of PGPR on growth and yield characteristics of pea On the basis of various plant growth promoting characteristics, nine isolates were selected and applied to the pea crop at the time of showing to evaluate their efficiency to enhance plant growth and yield characteristics under field conditions. The parameters studied were number of nodules per plant, plant height, number of pods per plant, pod length and fresh plant weight.

\section{Results}

\section{Isolation and enumeration of rhizobacteria from pea} rhizosphere

A total of 80 isolates were isolated. The most dominant isolates were identified as Bacillus sp (55), followed by Pseudomonas sp (12), Azotobacter sp (9) and Micrococcus $\mathrm{sp}$ (4). All the genera were tentatively identified following biochemical and morphological characterization.

\section{Plant Growth Promoting Characteristics}

Each isolate was screened for plant growth promoting traits such as siderophore production, phosphate solubulization, indole acetic acid production. Thirty isolates produced siderophores and the isolate PGP10 produced highest siderophore $(18 \mathrm{~mm})$ while least was observed in isolate PGP80 $(2.30 \mathrm{~mm})$ Table 1a. The ability to solubilize phosphate was positively exhibited by 43 isolates Table $1 \mathrm{~b}$. The isolate PGP72 showed maximum PSI (12.67) while minimum was noticed in isolate PGP35 (2.25). 40 isolates produce IAA that ranged from 2.10 to $25 \mu \mathrm{g} / \mathrm{ml}$ (Table $1 \mathrm{c}$ ).

Table 1a: Screening of PGPR, isolated from the rhizosphere of pea (Pisum sativum), for siderophore production

\begin{tabular}{|c|c|c|c|c|c|}
\hline S. No. & Isolates & Qualitative siderophore estimation (zone size, mm) & S. No. & Isolates & Qualitative siderophore estimation (zone size, mm) \\
\hline 1 & PGP1 & 16.00 & 16 & PGP33 & 6.80 \\
\hline 2 & PGP4 & 4.00 & 17 & PGP38 & 7.50 \\
\hline 3 & PGP5 & 7.52 & 18 & PGP40 & 11.00 \\
\hline 4 & PGP8 & 8.50 & 19 & PGP44 & 3.50 \\
\hline 5 & PGP9 & 7.00 & 20 & PGP49 & 14.60 \\
\hline 6 & PGP10 & 18.00 & 21 & PGP50 & 3.00 \\
\hline 7 & PGP12 & 3.15 & 22 & PGP52 & 17.50 \\
\hline 8 & PGP15 & 6.00 & 23 & PGP55 & 6.50 \\
\hline 9 & PGP19 & 6.50 & 24 & PGP62 & 10.00 \\
\hline 10 & PGP20 & 25 & PGP68 & 14.20 \\
\hline 11 & PGP22 & 11.00 & 26 & PGP71 & 8.50 \\
\hline 12 & PGP25 & 27 & PGP72 & 12.00 \\
\hline 13 & PGP28 & 14.00 & 28 & PGP76 & \\
\hline 14 & PGP30 & 8.50 & 30 & PGP 80 & \\
\hline 15 & PGP32 & 3.50 & & 8.00 \\
\hline
\end{tabular}

C.D $(p \leq 0.05): 0.345$ 
Table 1b: Screening of PGPR, isolated from the rhizosphere of pea (Pisum sativum), for phosphate solubilization

\begin{tabular}{|c|c|c|c|c|}
\hline S. No. & Isolate & Colony diameter $(\mathrm{cm})$ & Zone of clearance $(\mathrm{cm})$ & Solubilization Index (PSI) \\
\hline 1. & PGP1 & 0.41 & 1.50 & 4.66 \\
\hline 2. & PGP4 & 0.20 & 1.30 & 7.50 \\
\hline 3. & PGP5 & 0.50 & 1.30 & 3.60 \\
\hline 4. & PGP8 & 0.30 & 1.20 & 5.00 \\
\hline 5. & $\begin{array}{l}\text { PGP9 } \\
\end{array}$ & 0.80 & 1.20 & 2.50 \\
\hline 6. & PGP10 & 0.20 & 1.80 & 10.00 \\
\hline 7. & PGP13 & 0.70 & 1.70 & 3.43 \\
\hline 8. & PGP15 & 0.30 & 2.00 & 7.67 \\
\hline 9. & PGP17 & 0.50 & 1.30 & 3.60 \\
\hline 10. & PGP18 & 0.40 & 1.40 & 4.50 \\
\hline 11. & PGP20 & 0.30 & 1.20 & 5.00 \\
\hline 12. & PGP22 & 0.60 & 1.40 & 3.33 \\
\hline 13. & PGP23 & 0.60 & 1.50 & 3.50 \\
\hline 14. & PGP25 & 1.00 & 1.95 & 2.95 \\
\hline 15. & PGP28 & 0.20 & 2.30 & 12.50 \\
\hline 16. & PGP30 & 0.20 & 1.80 & 10.00 \\
\hline 17. & PGP32 & 0.80 & 1.00 & 2.26 \\
\hline 18. & PGP33 & 0.20 & 1.95 & 10.75 \\
\hline 19. & PGP35 & 0.80 & 1.00 & 2.25 \\
\hline 20. & PGP38 & 0.30 & 1.20 & 5.00 \\
\hline 21. & PGP39 & 0.30 & 1.30 & 5.33 \\
\hline 22. & PGP40 & 0.50 & 1.50 & 4.00 \\
\hline 23. & PGP42 & 0.30 & 1.70 & 6.67 \\
\hline 24. & PGP43 & 0.60 & 1.60 & 3.67 \\
\hline 25. & PGP44 & 0.80 & 1.40 & 2.75 \\
\hline 26. & PGP46 & 1.00 & 2.80 & 3.80 \\
\hline 27. & PGP48 & 0.70 & 1.50 & 3.14 \\
\hline 28. & PGP49 & 0.50 & 1.80 & 4.60 \\
\hline 29. & PGP50 & 0.20 & 1.60 & 9.00 \\
\hline 30. & PGP51 & 0.20 & 1.95 & 10.75 \\
\hline 31. & PGP52 & 0.60 & 1.90 & 4.17 \\
\hline 32. & PGP55 & 0.40 & 1.20 & 4.00 \\
\hline 33. & PGP58 & 0.30 & 1.60 & 6.33 \\
\hline 34. & PGP60 & 0.60 & 2.30 & 4.83 \\
\hline 35. & PGP62 & 0.20 & 1.65 & 9.25 \\
\hline 36. & PGP63 & 0.50 & 1.50 & 4.00 \\
\hline 37. & PGP65 & 0.70 & 1.90 & 3.71 \\
\hline 38. & PGP67 & 0.20 & 1.65 & 9.25 \\
\hline 39. & PGP68 & 0.80 & 1.00 & 2.27 \\
\hline 40. & PGP71 & 0.20 & 1.80 & 10.00 \\
\hline 41. & PGP72 & 0.30 & 3.50 & 12.67 \\
\hline 42. & PGP75 & 0.20 & 1.30 & 7.50 \\
\hline 43. & PGP77 & 0.30 & 1.50 & 6.00 \\
\hline
\end{tabular}

Table 1c: Screening of PGPR, isolated from the rhizosphere of pea (Pisum sativum), for Indole-3-acetic acid

\begin{tabular}{|c|c|c|c|c|c|}
\hline S. No & Isolate & Indole-3-acetic acid $(\boldsymbol{\mu g} / \mathbf{m l})$ & S. No & Isolates & Indole-3-acetic acid $(\boldsymbol{\mu g} / \mathbf{m l})$ \\
\hline 1 & PGP1 & 12.00 & 21 & PGP49 & 19.00 \\
\hline 2 & PGP2 & 18.00 & 22 & PGP50 & 20.50 \\
\hline 3 & PGP5 & 9.00 & 23 & PGP52 & 7.00 \\
\hline 4 & PGP6 & 13.50 & 24 & PGP55 & 12.50 \\
\hline 5 & PGP7 & 3.40 & 25 & PGP56 & 5.00 \\
\hline 6 & PGP10 & 25.00 & 26 & PGP58 & 15.50 \\
\hline 7 & PGP16 & 15.00 & 27 & PGP60 & 11.00 \\
\hline 8 & PGP18 & 12.50 & 28 & PGP62 & 14.00 \\
\hline 9 & PGP20 & 9.50 & 29 & PGP64 & 11.00 \\
\hline 10 & PGP25 & 21.00 & 30 & PGP65 & 6.50 \\
\hline 11 & PGP28 & 22.50 & 31 & PGP68 & 25.00 \\
\hline 12 & PGP30 & 4.00 & 32 & PGP70 & 14.50 \\
\hline 13 & PGP32 & 12.00 & 34 & PGP73 & 3.80 \\
\hline 14 & PGP36 & 9.50 & 35 & PGP74 & 11.00 \\
\hline 15 & PGP38 & 6.80 & 36 & PGP75 & 6.00 \\
\hline 16 & PGP39 & 5.50 & 37 & PGP76 & 9.50 \\
\hline 17 & PGP40 & 10.00 & 38 & PGP78 & 12.00 \\
\hline 18 & PGP42 & 12.00 & 40 & PGP80 & 2.10 \\
\hline 19 & PGP43 & 8.00 & & \\
\hline 20 & PGP44 & 5.50 & & PGP72 \\
\hline
\end{tabular}




\section{Soil analysis}

Physicochemical properties of soil are presented in Table 2. The soil $\mathrm{pH}$ ranged from 6.32 to 6.82 with highest $\mathrm{pH}$ observed in control (6.82) and lowest in isolate PGP49 (6.32). The organic carbon content was found in the range of 0.83 to 0.96 per cent with maximum content noticed in isolate PGP68 (0.96 \%) and minimum in control (0.83\%). The available nitrogen and phosphorus contents were highest in treatment PGP49 (291.52 kg/ha and $131.07 \mathrm{~kg} / \mathrm{ha})$ and lowest nitrogen and phosphorus contents was recorded in control $(280.65 \mathrm{~kg} / \mathrm{ha}$ and $107.20 \mathrm{~kg} / \mathrm{ha})$ respectively. However, highest potassium content was observed in treatment inoculated with isolate PGP62 $(86.37 \mathrm{~kg} / \mathrm{ha})$ in comparison to uninoculated control $(79.18 \mathrm{~kg} / \mathrm{ha})$.

Table 2: Physicochemical properties of soil

\begin{tabular}{|c|c|c|c|c|c|}
\hline Isolate & $\mathbf{p H}$ & $\begin{array}{c}\text { Organic carbon } \\
(\mathbf{\%})\end{array}$ & $\begin{array}{c}\text { Available nitrogen } \\
(\mathbf{k g} / \mathbf{h a})\end{array}$ & $\begin{array}{c}\text { Available phosphorus } \\
(\mathbf{k g} / \mathbf{h a})\end{array}$ & $\begin{array}{c}\text { Available potassium } \\
(\mathbf{k g} / \mathbf{h a})\end{array}$ \\
\hline Control & 6.82 & 0.83 & 280.65 & 107.200 & 79.187 \\
\hline PGP68 & 6.38 & 0.96 & 284.78 & 124.812 & 85.412 \\
\hline PGP10 & 6.51 & 0.90 & 287.34 & 124.249 & 82.703 \\
\hline PGP52 & 6.43 & 0.87 & 289.25 & 124.114 & 81.342 \\
\hline PGP28 & 6.56 & 0.86 & 289.73 & 120.029 & 86.078 \\
\hline PGP72 & 6.48 & 0.95 & 288.50 & 115.294 & 81.755 \\
\hline PGP49 & 6.32 & 0.90 & 291.52 & 131.077 & 79.770 \\
\hline PGP40 & 6.35 & 0.91 & 290.23 & 122.232 & 84.490 \\
\hline PGP01 & 6.52 & 0.95 & 287.51 & 125.057 & 81.760 \\
\hline PGP62 & 6.38 & 0.88 & 289.51 & 119.200 & 86.379 \\
\hline C.D (p $\leq 0.05)$ & 0.100 & 0.860 & 0.924 & 0.104 & 0.124 \\
\hline
\end{tabular}

\section{Effect of PGPR for growth and yield parameters of pea}

The data presented in Table 3 shows that the application of isolates increased the number of nodules, plant height, number of pods, fresh plant weight and pod length in all selected isolates as compared to control where no culture was applied. The isolate PGP49 showed increased number of nodules (60.44) as compared to control (40.70). Maximum plant height was recorded with respect to isolate PGP1 (47.53 $\mathrm{cm})$ while minimum was recorded in control $(44.12 \mathrm{~cm})$. The maximum number of pods was observed in isolate PGP68 (32.66) while it was minimum in control (21.33). Highest plant fresh weight was also recorded with respect to isolate PGP1 (427 g) than control (229 g). Highest pod length was recorded in isolate PGP62 $(8.52 \mathrm{~cm})$ and lowest in control $(6.55 \mathrm{~cm})$

Table 3: Effect of selected isolates of PGPR for growth and yield characteristics on pea rhizosphere

\begin{tabular}{|c|c|c|c|c|c|}
\hline Isolate & Number of nodules per plant & Plant height (cm) & Number of pods per plant & Plant fresh weight (g) & Pod length (cm) \\
\hline Control & 40.70 & 44.127 & 21.334 & 229 & 6.559 \\
\hline PGP68 & 54.20 & 46.712 & 32.667 & 397 & 8.342 \\
\hline PGP10 & 58.78 & 46.305 & 29.667 & 377 & 7.657 \\
\hline PGP52 & 58.69 & 44.727 & 30.000 & 282 & 8.270 \\
\hline PGP28 & 49.76 & 45.217 & 31.500 & 312 & 7.289 \\
\hline PGP72 & 52.85 & 45.679 & 29.667 & 364 & 7.375 \\
\hline PGP49 & 60.44 & 45.087 & 28.334 & 362 & 8.308 \\
\hline PGP40 & 57.90 & 45.112 & 29.167 & 360 & 6.785 \\
\hline PGP01 & 47.92 & 47.535 & 29.667 & 427 & 7.570 \\
\hline PGP62 & 54.94 & 44.130 & 29.000 & 357 & 8.522 \\
\hline C.D $(p \leq 0.05)$ & 1.072 & 0.588 & 1.146 & 0.121 & 0.253 \\
\hline
\end{tabular}

\section{Discussion}

Rhizosphere is a rich habitat for microorganisms and should be explored for obtaining potential PGPR, which can be useful in developing bioinoculants for enhancement of growth and yield of crop plants. The beneficial effect of plant growth promoting rhizobacteria, particularly those belonging to the genus Bacillus or Pseudomonas, in enhancing growth and overall plant establishment is well established. This has been attributed to various mechanisms, such as providing fixed nitrogen to the host plant, production of phytohormones, solubilization of insoluble phosphate, production of metabolites, including antibiotics and siderophores (Compant et al., 2005) ${ }^{[5]}$.

The results of the present studies, based on the rhizobacteria isolation on the rich media and classification of the isolates on the morphological and biochemical features, can be criticized. In our study, four different genera were identified viz. Bacillus, Pseudomonas, Micrococcus, and Azotobacter.

In our study, Bacillus (55) was dominant group. Bacillus species are also a major component of the microbial flora, which live in close association with various types of agricultural crops. Many authors cite Pseudomonas as the dominant genus in the rhizosphere, probably because under favorable environmental conditions, its growth rate is higher than that of Bacillus (Bowen \& Foster, 1978) [3]. Predominance of Bacilllus sp. is due to its ability to efficiently use the nutrients provided by the plant through exudates. In additions, Bacillus has the ability to inhibit the growth of other strains. Many strains of Bacillus have been reported to produce substances that act as growth inhibitors for other microorganisms (Lilinares et al., 1994) ${ }^{[16]}$. However, previous study shows Bacillus as the dominant genus in the rhizosphere of Elaeagnus angusti folia L. (Ramos, 1998) ${ }^{[23]}$.

The results show $37.5 \%$ isolates have ability to produce siderophore on CAS agar medium, 53\% isolates solubilize phosphate and $50 \%$ produce IAA. These results indicate that the tested isolates could exhibit two or three plant growth promoting (PGPR) traits, which may promote plant growth directly, indirectly, or synergistically. In corroboration to our 
findings multiple PGP activities among PGPR have been reported by some other investigators (Gupta et al., 1998; Dey et al., 2004) ${ }^{[10,7]}$. Several studies have demonstrated that production of siderophore by PGPR was most effective in controlling the plant root pathogens (Mullen, 1998; Diaz et al., 2002; and Dey et al., 2004) [20, 8, 7]. The potential to produce siderophores by microorganisms in improving iron availability to plants was also reported by some workers (BarNess et al., 1992; Rroco et al., 2003; Sharma et al., 2003) ${ }^{[1,}$ 24, 26]. Phosphate solubilization is considered to be the most important attribute of plant growth promoting rhizobacteria (Kloepper et al., 1989) ${ }^{[15]}$. Bacterial IAA stimulates the development of the host plant root system.

\section{References}

1. Barness E, Hadar Y, Chen Y, Romheld V, Marschner H. Short term effects of rhizosphere microorganisms on $\mathrm{Fe}$ uptake from microbial siderophores by maize and oat. Plant Physio. 1992; 100:451-456.

2. Benizri E, Baudoin E, Guckert A. Root colonization by inoculated plant growth promoting rhizobacteria. Bio Sci Tech. 2001; 11:557-574.

3. Bowen GD, Foster RC. Dynamics of microbial colonization of plant roots. In: Soil Microbiology and Plant Nutrition, (eds) Broughton, W.J. and John C.K, 1978, 98101p.

4. Brick JM, Bostock RM, Silverstone SE. Rapid in situ assay for indoleacetic acid production by bacteria immobilized on nitrocellulose membrane. Appl. Environ. Microbiol. 1991; 57:535-538.

5. Compant S, Duffy B, Nowak J, Clement C, Barka EA. Use of plant growth-promoting bacteria for biocontrol of plant disease: principles, mechanisms of action, and future prospects. Appl. Environ. Microbial. 2005; 71:4951-4959.

6. Davies DR, Berry GJ, Heath MC, Dawkins TCK. Pea (Pisum sativum L.). 1985; 147-198.11.

7. Dey R, Pal KK, Bhatt DM, Chauhan SM. Growth promotion and yield enhancement of peanut (Arachis hypogaea L.) by application of plant growth promoting rhizo bacteria. Microbiol. Research. 2004; 159:371-394.

8. Diaz ME, Villa P, Frias A. Evaluation of the siderophores production by Pseudomonas aeruginosa PSS. Revista Latioamericana de Microbioloogia. 2002; 44:112-117.

9. FAO. Forest Resources Assessment 1990- non-tropical developing countries Mediterranean region. FO: MISC/94/3. Rome, 1994.

10. Gupta AK, Saxena G, Murali Tilak, KVBR. Effect of plant growth promoting rhizobacteria on competitive ability of introduced Brady rhizobium sp. (Vigna) for nodulation J. Sci. Ind. Res. 1998; 57:720-725.

11. Hiltner L. Uber neuere Erfahrungen und Probleme auf dem Gebiet der Bodenbakteriologie und unterbesonderer Berücksichtigung der Gründüngung und Brachte. Arbeiten der Deutschen Landwirtschaftlichen Gesellschaft. 1904; 98:59-78.

12. Jackson ML. Soil chemical analysis. New Delhi. 1967, 111-203.

13. Johnson LF, Curl EA. Methods for research on ecology of soil-borne plant pathogens. Burgess, Minneapolis, Minn, 1972.

14. Kloepper JW, Schroth MN. Plant growth promoting rhizobacteria on radishes. In: Proceeding of the 4th International Conference on Plant Pathogenic Bacteria.
Vol. 2, (pp. 879- 882) Station de Pathologie Vegetaleet Phytobacteriologie, INRA, Angers, France, 1978.

15. Kloepper JW, Lifshitz R, Zablotowitz RM. Free living bacteria inocula for enhancing crop productivity. Trends Bio technol. 1989; 7:39-43.

16. Lilinares F, MuñozMingarro D, Pozuelo JM, Ramos B, Bermúdez, de Castro F. Microbial inhibition and nitrification potential in soils incubated with Elaeagnus angustifolia L. leaf litter. Geo microbioogy Journal. 1994; 11:1491-56.

17. Lugtenberg BJJ, Bloemberg GV, Bolwerk A, vanden Broek D, Cazorla Lopez F, Chin A Woeng TFC et al. Biocontrol of pathogens. In: Biology of plant microbes interactions, (eds) Tikhonovich I., Lugtenberg, B.J.J., Provorov, N. vol 4th International Society for Molecular Plant Microbe Interactions, St Paul, Minnnesota. USA, 2004, 305-309p. ISBN: 0-954625-3-6.

18. Lugtenberg BJJ, Dekkers L, Bloemberg GV. Molecular determinants of rhizosphere colonization by Pseudomonas. Annu. Rev. Phytopathol. 2001; 39:461490.

19. Muhur RN, Datta NP, Sankar Subramoney H, Leley VK, Vay Donaline L. Soil testing in India. U.S. Agency for international development mission to India, 1965, 39, 40, 45.

20. Mullen MD. Transformations of other elements. In: Principles and Applications of Soil Microbiology. Prentice Hall, New Jersey, USA, 1998, 369-386p.

21. Nelson LM. Plant growth promoting rhizobacteria (PGPR): Prospects for new inoculants. Online Crop Management, 2004. doi: 10.1094/CM2004-0301-05-RV.

22. Pikovskaya RE. Mobilization of phosphorus in soil in concentration with vital activity of some microbial species. Microbiologia. 1948; 17:362-370.

23. Ramos B, Pozuelo JM, Acero N. Gutierrez Manero FJ, Seasonal variation of Bacillus isolates from the rhizosphere of Elaeagnus angustifolia L. Orsis. 1998; 13:7-16.

24. Rroco E, Kosegarten H, Harizaj F, Imani J, Mengel K. The importance of soil microbial activity for the supply of iron to sorghum and rape. Europ. J Agronomy. 2003; 19:487493.

25. Schwyn B, Neilands JB. Universal chemical assay for the detection and determination of siderophore. Anal. Biochem. 1987; 160:47-56.

26. Sharma A, Johri BN, Sharma AK, Glick BR. Plant growth promoting bacterium Pseudomonas sp., strain GRP3 influences iron acquisition in mung bean (Vigna radiate L. Wilzeck). Soil Biol. Biochem. 2003; 35:887894.

27. Stanford S, English. Use of flame photometer in rapid soils tests for potassium and calcium. Agronomy Journal. 1949; 41:446-447.

28. Subbiah BV, Asija GL. A rapid procedure for estimation of available nitrogen in soils. Current Sciences. 1956; 25:259-260. 